\title{
For lege og student - mannskoret Foetus ex Ore 20 år
}

\author{
To årtier med klangfull og bejublet mannssang ved medisinstudiet i Trondheim er tilbakelagt. Prognosen \\ quoad vitam er fortsatt sterk og god.
}

Trond Nordseth

trond.nordseth@ntnu.no

Klinikk for anestesi og intensivmedisin St. Olavs hospital

Foetus ex Ore er et toneangivende (sic!) mannskor ved Det medisinske fakultet, Norges teknisk-naturvitenskapelige universitet i Trondheim. Stiftelsen foregikk 17. mars 1993 under en beleven «middag Constitutionalis Foetus ex Oria», og av korets vedtekter og kjenningsmelodi Foetus Fanfaren fremgår det at koret er for «lege og student». Foetus ex Ore er latin og kan fritt oversettes til «oral forløsning». Koret feiret 20 -års jubileum helgen $8 .-10$. november 2013. En systematisk gjennomgang av korets aktiviteter er tidligere ikke blitt gjort i Tidsskriftet.

\section{Materiale og metode}

Korets sangere benevnes Lemmer og består av medisinstudenter og yrkesaktive leger. Koret øver hver tirsdag og ledes av en kvinnelig dirigent kalt Frøken. Koret har regelmessige sangoppdrag året rundt og har et internt reiseselskap, Foetus Pegasus. Korets leder benevnes Primarius, og styret består ellers av Notarius (sekretær, med ansvar for annalene), Numismaticus (økonomi), Magister spiritualis (festansvarlig) og Procurator amicitia (PR-ansvarlig). Koret har et ryddig og profesjonelt forhold til Bilyd, et kor for piker ved samme fakultet. En julekonsert avholdes hvert år sammen med disse, med vekslende hell. Av øvrige faste arrangementer har Foetus sitt julebord, Julius, årsmøtet Sirius og vårfesten Vårius. Alle sangere opptatt i koret beæres med eget latinsk navn som gjenspeiler deres karakter. Aspiranter tiltales nedlatende som meconium (liten $\mathrm{m}$ ). Aktive sangere regnes til Pars praesens, mens sangere etter fullført studium rykker opp i hedersgruppen Pars senilis. Pars necrosis betegner lemmer som har gått ut. Tilsvarende overflyttes lemmer med permisjon til den utsatte gruppen Pars ischemica. Koret har et geriatrisk gissel i Geir W. Jacobsen (Lem emeritus).

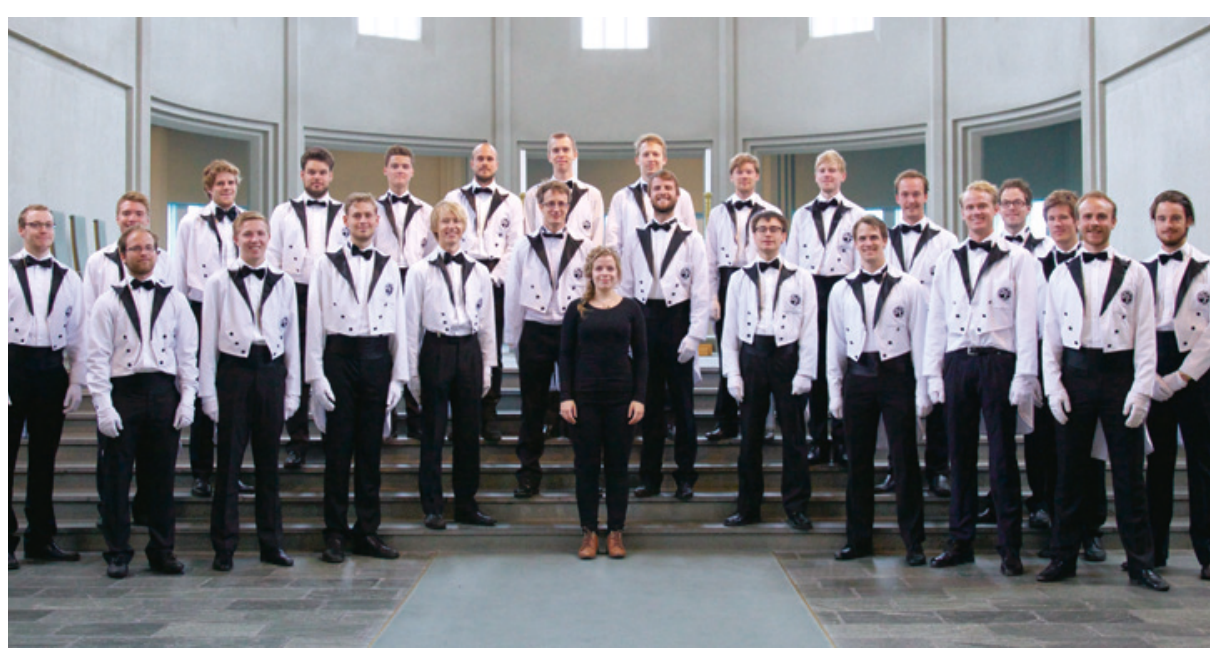

Mannskoret Foetus ex Ore i Hallgrímskirkja, Reykjavík. Artikkelforfatter er nummer fire fra høyre. Foto: Lem Larsen

\section{Resultater}

Koret teller i dag 30 aktive sangere og i løpet av studieperioden har nærmere 140 medisinstudenter vært med i Foetus ex Ore. $\mathrm{Ni}$ kvinnelige dirigenter har ledet koret, inkludert dagens dirigent, Janne Kristin Schanke. Koret har vært på turer til Reykjavik (1997, 2013), Praha (1998, 2008), Jerusalem/Beer Sheva (2000), Berlin (2001), Edinburgh (2004), Budapest (2010) og Krakow (2011). Artikkelforfatteren har deltatt på sju av disse turene. Basert på foreliggende bildemateriale kan det dokumenteres en sosialfaktor ispedd mat og drikke som er signifikant høyere enn utgangsverdien på lesesalen $(\mathrm{p}<0,001)$. Koret har fått komponert egne kantater bestående av 4-6 sanger av komponist Knut A. Vestad til flere av turene. Til årets jubileumsarrangement ble det komponert en egen jubileumskantate av komponist Geir D. Gjerdsjø.

Jubileumshelgen fikk navnet Jubilus 2013 og ble feiret av koret i nærvær av nærmere 30 tilreisende Senile lemmer. En storslått jubileumskonsert ble arrangert i Erkebispegårdens konsertlokale Eysteinsalen med nær 300 fremmøtte. Jubileumskantaten omfattet Helsedirektoratet informerer, Allmennlegens klagesang, Ølbryggervise og Pia. Sistnevnte er en elegi over korets nå nedlagte stamlokale. Jubileumsmiddagen ble avholdt i ærverdige Klubbselskabet Harmonien, mens øvrige festligheter foregikk i Sjømannsforeningens lokaler. Til jubileet ble det stappet og røkt egne pølser, og engasjerte bryggere fra korets rekker serverte et eget Jubilus-øl. En jubileumsbok er trykt for anledningen.

\section{Konklusjon}

Foetus ex Ore lever i beste velgående etter 20 innholdsrike år. Koret har en stabil og velklingende sangerskare og ser frem til de neste 20 år under mottoet FFF - Fremgang For Foetus!

\section{Trond Nordseth (f. 1977)}

er overlege og andrebass i mannskoret Foetus ex Ore.

Forfatter har fylt ut ICMJE-skjema og oppgir ingen interessekonflikter.

Mottatt 18.11 og godkjent 20.11. Redaktør: Erlend Hem. 